\title{
La vida es sueño, de Calderón de la Barca - ante el tribunal de la Kallipolis y el veredicto de Schopenhauer
}

\author{
La vida es sueño, de Calderón de la Barca - ante el tribunal de la \\ Kallipolis y el veredicto de Schopenhauer
}

\author{
Guilherme Marconi Germer \\ Pós-doutorando em Filosofia pela USP. \\ E-mail: guilhermeguita@gmail.com \\ Natalia Costa Rügnitz \\ Doutoranda em Filosofia pela UNICAMP e pela Tübingen Universität \\ E-mail: natalia.costa.rugnitz@gmail.com
}

\begin{abstract}
Resumo: En este artículo nos proponemos arrojar luz sobre la asimilación de Schopenhauer de la teoría de la Ideas de Platón y su distanciamiento del antiguo bajo la concepción de que el medio facilitador del conocimiento de la Idea es el arte, con una especie de "análisis de caso": comentaremos como para Schopenhauer, La Vida es Sueño, de Calderón de la Barca, expone tres perspectivas filosóficas fundamentales: (1) el idealismo, basado en la concepción de que "el mundo es mi representación"; (2) el "sentido verdadero de la tragedia", fundado en la lección de que los héroes "no expían sus pecados individuales sino el pecado original, la culpa de la propia existencia"; y (3) la justicia eterna, apoyada en la sabiduría de que "el mundo es el tribunal del mundo", y que así, el destino y índole moral del mundo están íntimamente conectados.
\end{abstract}

Palavras-chave: Ideas Eternas; Idealismo; Tragedia; Justicia Eterna; Poesía Barroca; Moralidad.

\begin{abstract}
In this article, we propose to shed light on Schopenhauer's assimilation of Plato' $s$ theory of Ideas and his distancing from the Greek under the conception that the facilitating medium of the knowledge of the Idea is art, with a kind of "case analysis": we will comment on, how for Schopenhauer, Life is a Dream, by Calderón de la Barca, exposes three fundamental philosophical perspectives: (1) idealism, based on the conception that "the world is my representation"; (2) the "true meaning of tragedy", founded on the lesson that heroes "do not expiate their individual sins, but original sin, the guilt of their own existence"; and (3) eternal justice, supported by the wisdom that "the world is the tribunal of the world", and thus the destiny and moral character of the world are intimately connected.
\end{abstract}

Keywords: Eternal Ideas, Idealism, Tragedy, Eternal Justice, Baroque Poetry, Moral. 


\section{I}

( Schopenhauer estaba íntimamente persuadido de que solo cabe acceder a las verdades más profundas y recónditas a través de los mitos, de las interpretaciones alegóricas, en una palabra, de las metáforas"1 - escribe Aramayo. Tal convicción, en efecto, probablemente constituya la fuerza motriz que impulsa al pensador alemán, como no pocas veces se transparenta en sus escritos, hacia el dominio de la poesía y la literatura y, de modo adyacente, de la mística y la religión. Shakespeare y Goethe, así como textos sagrados como el Mahabharata o los Upanishads, son visitados recurrentemente por Schopenhauer para iluminar este o aquel aspecto de su filosofar, de modo que el lector percibe la admiración y el aprecio del autor por el arte y las manifestaciones culturales extra-filosóficas antes aún de penetrar las minucias de su peculiar teoría estética. Esta apertura y receptividad en relación al universo artístico en general y literario en particular, que bien podría considerarse enriquecedora y fértil, provoca en ocasiones, sin embargo, la reacción contraria: atravesado por tales excursiones, el pensamiento de Schopenhauer es considerado "menos riguroso" y, por eso, marginalizado. Así, Schopenhauer es frecuentemente admirado por literatos de la estirpe más fina como Mann, Kafka, Cioran, Guy de Maupassant, Antonio Machado, J. L. Borges, etc., pero segregado, sea explicita, sea implícitamente, por profesores y manuales de filosofía dentro de la Academia. ¿A qué se debe este desdeño? He aquí nuestra hipótesis: debido a esta predilección suya, Schopenhauer parece situarse en las antípodas de cierta tradición, de larga data y de cuño platónico, para la cual las expresiones artísticas son “inferiores", un obstáculo para el conocimiento y el desarrollo de la inteligencia - algo adverso, e inclusive pernicioso, para el perfeccionamiento moral e intelectual.

Detengámonos un instante en la "cuestión platónica”. Existe una manera difundida de interpretar un conjunto de pasajes de la República según la cual Platón es contrario al arte y destierra a los poetas de la ciudad ideal. El motivo del destierro podría resumirse de la siguiente manera: para el Platón de República, la poesía y el teatro, y en general los productos de todas las artes imitativas en su conjunto, se encuentran "alejadas tres veces de lo real"2. Supongamos, para aclarar este dictamen y tal como lo hace Sócrates, un pintor que retrata una mesa. Con el fin de evaluar la creación del artista, Sócrates sugiere pensar

\footnotetext{
${ }^{1}$ ARAMAYO, R. Los Designios del Destino, p. 23.

2 PLATÓN. República X 597e; 599a.

La vida es sueño, de Calderón de la Barca - ante el tribunal de la Kallipolis y el veredicto de Schopenhauer
} 
en términos de jerarquía ontológica: en el nivel más alto de la escala, gozando de un estatuto supremo en cuanto al grado "de realidad" o "de ser", se encuentra la Idea de mesa: modelo original, arquetipo invisible para los ojos del cuerpo pero "visible para los ojos del alma" (la inteligencia), idéntico a sí mismo en todos los casos y por consiguiente atemporal, eterno e inmutable; en seguida, se encuentra la obra del carpintero que construye una mesa, esta sí accesible a los sentidos y sujeta a las transformaciones propias del devenir, sujeta a "ser y después no ser"3, es decir: una entidad no ya idéntica y estable sino relativa y evanescente; en un tercer momento, finalmente, se sitúa la obra del artista, que observa la mesa del carpintero y lleva al lienzo alguna de sus innúmeras perspectivas, esto es: la mesa vista de frente, o lateralmente, etc. Tal es el significado del dictamen socrático según el cual los productos de las artes miméticas se encuentran "alejados tres veces de lo real". El artista crea una "copia de una copia”, un "simulacro de un simulacro", una "imitación no de la realidad sino de la apariencia"4 que ejerce un influjo sobre las partes irracionales del alma, en particular sobre la emoción (thumoeidés) ${ }^{5}$. Y esto vale también para el arte dramático: sobre las tablas, el actor que da vida a los personajes de la tragedia o la comedia no hace sino imitar, sin estar en posesión de un conocimiento verdadero de aquello que reproduce, suscitando en los espectadores reacciones irracionales de las más diversas índoles. Cuanto mejor actor sea, tanto más eficiente será en "engañar a niños y hombres insensatos"6 con su arte. Seducidos por el espectáculo, y motivados además ellos mismos por la irresistible potencia de la imitación, natural al alma humana según Platón, el público se verá inclinado a reproducir los comportamientos y valores transmitidos por los artistas. Esto en consideración, y dado además el elitismo platónico, según el cual la mayoría, oi polloi, de los hombres (o, en el caso de la República, de los ciudadanos, cuya mejor vida posible se procura) son "como niños", insensatos y de inteligencia limitada, surge entonces la famosa "expulsión de los poetas". Figurándose, por ejemplo, un artista que se presentara ante el rey-filósofo de la Kallipolis con el don de representar "todas las cosas", Platón escribe: "Le diríamos que en nuestra ciudad no hay

\footnotetext{
3 PLATÓN. República V 476d et seq.

4 PLATÓN. República X 598b.

${ }^{5}$ En la República, y también en otros diálogos como el Fedro, Platón avanza una teoría tripartida del alma, según la cual la misma es un compuesto de razón (logistikón), emoción (thumoeidés) y apetito (epithumetikón, Cf. COSTA RUGNITZ, N. Estrutura e Dinâmica da psyché na República, p. 13 et seq.). Los dos últimos elementos son, por definición, privados de logos, relacionados antes a la sensibilidad y lo sensible (Cf. PLATÓN. República IV 436 et seq.); el arte, para Platón, está dirigido a ellos.

${ }^{6}$ PLATÓN, República X 598c.

La vida es sueño, de Calderón de la Barca - ante el tribunal de la Kallipolis y el veredicto de Schopenhauer
} 
ningún hombre de este tipo y que es justo que no lo haya; derramaríamos mirra sobre su cabeza y le coronaríamos con cintas, enviándolo a otro país"7.

Grosso modo, esta es la base argumental que subyace a la interpretación ampliamente extendida, incluso en la filosofía contemporánea ${ }^{8}$, que atribuye a Platón la "fama de ser el filósofo que repudió el arte, la poesía, la tragedia, la comedia y la acción dramática en cuanto tal"9. A pesar de reconocer en el discípulo de Sócrates a uno de "los dos mayores filósofos de Occidente" ${ }^{10}$, debido a su memorable lección sobre las Ideas ${ }^{11}$, en lo que toca a la teoría del arte Schopenhauer parece alinearse a la exégesis tradicional, cuando dice:

Platón enseña (República X, 597d-598a) que el objeto cuya exposición intenta el arte, el modelo de la pintura y de la poesía, no sería la Idea, pero sí la cosa individual. Mi visión entera del arte y de lo bello afirma justamente lo contrario, y tampoco la opinión de Platón nos hará errar. En verdad, ella es la fuente de uno de los mayores y más reconocidos errores de aquél gran hombre, es decir, el desprecio y rechazo del arte, en especial de la poesía ${ }^{12}$.

De un modo un tanto herético, Schopenhauer avanza una concepción del arte que, a pesar de erguirse a partir de la Idea platónica, invierte completamente la concepción de República: la obra de arte es, para Schopenhauer, una creación propia del genio y, en tanto tal, el medio facilitador de la Idea o del conocimiento de la Idea. En palabras del autor:

[El genio] solo contempla la Idea y no la realidad; en su obra, solo reproduce aquella, aislándola y haciendo caso omiso de toda contingencia perturbadora $[\mathrm{y}]$ nos hace ver el mundo con sus ojos. Lo propio del genio [...] es que su mirada descubre lo más esencial de las cosas, lo que éstas son en sí y fuera de toda relación; pero la facultad de hacernos ver a nosotros, de prestarnos su mirada, esto es lo adquirido, la técnica del arte ${ }^{13}$.

\footnotetext{
7 PLATÓN. República III 398a.

8 Dice Heidegger, por ejemplo: “¿Que la filosofía platónica, que solemos presentar como la flor del pensamiento griego, haya desacreditado el arte! He ahí un hecho desconcertante, y sin embargo, incontestable" (HEIDEGGER, M. Nietzsche. p. 191 apud BENOIT, H. Em busca da Odisséia dialógica, p. 6).

${ }^{9}$ BENOIT, Héctor. Ibídem, p. 4.

${ }^{10}$ El otro es Kant. Cf. SCHOPENHAUER, A. $W W V$, p. 247. MVR, p. 236.

${ }^{11}$ Cabe alertar desde ya que el término Idea varía en su significado de Platón a Schopenhauer. Resumidamente, para el alemán, las Ideas platónicas constituyen el ápice del conocimiento del mundo en cuanto representación. Nos debruzaremos sobre esta distinción más adelante.

12 SCHOPENHAUER, A. MVR, §41, p. 286.

13 SCHOPENHAUER, A. MVR, §37, p 265.

La vida es sueño, de Calderón de la Barca - ante el tribunal de la Kallipolis y el veredicto de Schopenhauer
} 
¿Cuál es el punto en el cual Schopenhauer se distancia de su admirado maestro Platón? ¿Cuáles los motivos que lo llevan a elaborar una concepción del arte aparentemente tan opuesta a la del antiguo? Con el fin de arrojar luz sobre estas perplejidades, traeremos a continuación una especie de "análisis de caso", esto es: un ejemplo de creación artística "genial" que, si la concepción del filósofo alemán es correcta, "facilitará la intuición" de la idea y permitirá "acceder a verdades profundas y recónditas"14.

\section{II}

Schopenhauer, explícitamente adverso a las repeticiones, se refiere a La Vida es Sueño, del dramaturgo español Calderón de la Barca, en tres pasajes diferentes de El Mundo como Voluntad y Representación. En el Libro I de su obra capital, Schopenhauer anota que el drama calderoniano trae a la intuición imaginativa una de las principales lucideces del idealismo filosófico, basado en la concepción de que "el mundo es mi representación", a saber: el hecho de que el mundo sea, en lo que atañe a su forma, algo comparable a un sueño. En el Libro III aparece la segunda referencia, donde Schopenhauer dice que la obra de Calderón expone con gran primor el "sentido verdadero de la tragedia", a saber: que los héroes "no expían sus pecados individuales sino el pecado original, la culpa de la propia existencia”. Finalmente, el filósofo hace una tercera referencia a La Vida es Sueño en el cuarto libro de El Mundo..., al afirmar que la obra prepara al lector de modo singular para el "conocimiento mejor" de la justicia eterna - la cual, según Schopenhauer, constituye el principio de la virtud y de la ascesis.

Desde el punto de vista de la filosofía de Schopenhauer, estudiar las distintas referencias a la obra calderoniana puede interesar no solo para poner en evidencia el "pensamiento único" de los escritos del alemán, sino sobre todo para fundamentar su sugerencia de que la epistemología, la estética y la ética constituyen puntos de vista distintos de un solo mundo - mundo que, a su vez, es la expresión de una sola voluntad. Finalmente, y retomando el asunto del apartado anterior, una indagación acerca de cómo una obra teatral puede enseñar tantas lecciones de modo intuitivo y sintético tiene también la finalidad de contestar el racionalismo que define el arte como un modo de

${ }^{14}$ ARAMAYO, R. Los Designios del Destino, p. 23.

La vida es sueño, de Calderón de la Barca - ante el tribunal de la Kallipolis y el veredicto de Schopenhauer 
conocimiento y cultivo de la virtud inferior al científico o, como para Hegel, inferior incluso al religioso.

Así justificada la pertinencia del asunto que nos convoca, diremos a seguir una palabra sobre la organización del texto. En primer lugar haremos una breve presentación de la figura de Calderón de la Barca y de la estética barroca de su escritura, resumiendo la trama de La vida es Sueño. En seguida, consideraremos las tres referencias antedichas de Schopenhauer a tal obra. Hacia el final del recorrido, sintetizaremos el argumento de Schopenhauer de que el arte es el principal medio de conocimiento de la Idea, mientras que las ciencias, que trabajan menos con ideas y más con conceptos, son más útiles que profundas.

\section{III}

Pedro Calderón de La Barca (1600-1681) es un escritor, poeta y dramaturgo, cuya extensa obra constituye uno de los exponentes más significativos de la literatura barroca española. Según A. V. Briones, su obra puede ser dividida en dos grupos: el primero es más condensado, organizado y "cortesano"15, despliega una preciosa galería de personajes que reflejan el tiempo y la condición social de Calderón, siempre en torno a los tres temas principales del teatro barroco español: el amor, el honor y la religión ${ }^{16}$. En el segundo registro de la producción calderoniana, el poeta va más allá del repertorio caballeresco e inventa una nueva forma expresiva que configura un teatro fundamentalmente lírico, cuyos personajes dan un giro hacia lo simbólico y lo espiritual. Calderón escribe entonces dramas filosóficos y teológicos, comedias mitológicas o palatinas y autos sacramentales. La Vida es Sueño pertenece a esta etapa ${ }^{17}$.

Publicada en 1635, La Vida es Sueño no solo ocupa una posición única en la literatura española, sino que es una de las pocas obras de ese origen corrientemente incluidas entre las obras maestras de la literatura universal ${ }^{18}$. Se trata de "una de las obras

\footnotetext{
15 Cf. BRIONES, A. V. Ensayo Sobre la Obra de Calderón. Madrid: Ateneo, 1958. El primer grupo surge bajo la fuerte influencia de Lope de Vega. Algunos de los títulos principales de este periodo son: El alcalde de Zalamea, El mayor monstruo, Los Celos, El médico de su honra, etc.

16 BRIONES, A. V. Ibídem.

17 Otras piezas consagradas de esa fase son: El Príncipe Constante, El Mágico Prodigioso La Cena del Rey Baltasar, El Secreto a Voces etc.

18 Cf. STROUD, M. D. Pedro Calderón de la Barca. In: Spanish Dramatists of the Golden Age: A Bio-Bibliographical Sourcebook, p. 42. 
más filosóficas"19 de Calderón o, como dice Schopenhauer, de un "drama metafísico"20.

La trama se desarrolla en la Polonia medieval. El protagonista es el Príncipe Segismundo y la dama Rosaura. Otros personajes son: Clarín, el bufón; Basilio, el rey; Astolfo, duque de Moscovia; Estrella, la infanta y Clotaldo, el anciano. La historia se divide en tres actos dramáticos o "jornadas", siendo que en la primera expone el sufrimiento del héroe Segismundo; en la segunda, su odio y cólera contra las causas y los causantes de su condición; en la tercera, su liberación, gracias a la asimilación de la lección que titula el drama.

La Primera Jornada se inicia así: Rosaura y Clarín buscan, a campo traviesa, un abrigo para protegerse de la noche. Al entrar en una torre oscura, escuchan a un prisionero lamentándose con las siguientes palabras:

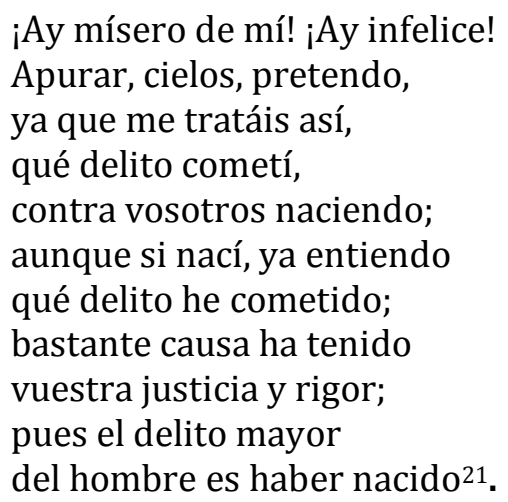

Quien de esta manera murmura es el príncipe Segismundo, que, como se revelará posteriormente, ha sido hecho prisionero inmediatamente después de su nacimiento y por dos razones que le son desconocidas: la primera es que su nacimiento fue la causa del fallecimiento de su madre; la segunda, que los estudios astrológicos del rey Basilio, su padre supersticioso, le advirtieron que Segismundo lo mataría y sería un rey tirano. El único contacto que el príncipe tiene con el mundo ocurre por medio de las visitas de Clotaldo, vasallo del rey Basilio encargado de alimentar y educar al prisionero bajo orden real. El príncipe, condenado sin saber cuál ha sido el crimen cometido, encuentra justificación para su desdicha en la alegoría cristiana del pecado original, tergiversada en las palabras: "El delito mayor / del hombre es haber nacido". Según el cristianismo, nascer

${ }^{19}$ STROUD, M. D. Ibídem.

20 SCHOPENHAUER, A. $W W V$, p. 50.

${ }^{21}$ CALDERÓN DE LA BARCA, P. La vida es sueño, p. 1, grifo nuestro.

La vida es sueño, de Calderón de la Barca - ante el tribunal de la Kallipolis y el veredicto de Schopenhauer 
y crecer fuera del paraíso, es decir, en este mundo, son dos actos que derivan de la desobediencia de Adán y Eva. Aunque el mito cristiano "explica” a Segismundo la causa de su dolor, resta aún para él la siguiente duda: “ ¿No nacieron [también] los demás? / Pues si los demás nacieron / ¿qué privilegio tuvieron / del que yo no gocé jamás?’22.

Hacia el final de la Primera Jornada y luego del lamento de Segismundo, escuchado secretamente por Rosaura y Clarín, una gracia repentina viene a aliviar el tormento del cautivo: iluminado por la idea de que no es un "acto cristiano" continuar castigando a su hijo tan severamente, el rey manda buscar al príncipe y traerlo a la corte, ante a la cual revelará la ignota existencia de Segismundo, poniendo a prueba el carácter moral y el destino del príncipe. Aunque siga confiando en la previsión astrológica acerca del carácter maligno de Segismundo, Basilio acepta la posibilidad del libre albedrío contra las imposiciones de la personalidad y del destino. Dice el rey: “Aunque su inclinación / Le dicte sus precipicios, / Quizá no le vencerán / Porque el hado más esquivo, / La inclinación más violenta, / El planeta más impío, / Sólo el albedrío inclinan, / No fuerzan el albedrío”23. Apoyándose en esta idea, el rey formula un plan altamente ingenioso para darle a Segismundo la oportunidad de vencer a la "fuerza del destino" con la educación cristiana recibida de Clotaldo: Basilio ordena que su hijo sea adormecido con una droga y conducido al palacio real, donde, al despertarse, sería tratado naturalmente como un rey. En el caso de que Segismundo supiera perdonar a su padre y mostrarse humilde, sería reconocido como legítimo sucesor; de lo contrario, sería nuevamente envenenado y conducido a la cárcel, donde despertaría y creería que todo lo sucedido no era más que un sueño.

Frente a los asombrados ojos de Rosaura y Clarín, que observan todo escondidos, el plan es puesto en práctica en la Segunda Jornada. Segismundo se despierta en el palacio real, es avisado de su historia y se torna una fiera vengativa. En medio a ataques de odio mata a un criado que intentaba contenerlo, agrede verbalmente al rey y a todos los que se le aproximan. En vista de este su comportamiento, el príncipe es nuevamente envenenado y devuelto a la cárcel.

Al día siguiente, cuando despierta en el claustro, Segismundo mal puede hacer sentido de lo sucedido. Bajo orden real, Clotaldo lo convence de que todo no ha sido más que un sueño, a lo cual el príncipe responde con un cambio radical de carácter. En lugar

22 CALDERÓN DE LA BARCA, P. Ibídem.

23 CALDERÓN DE LA BARCA, P. Ibídem. P. 35.

La vida es sueño, de Calderón de la Barca - ante el tribunal de la Kallipolis y el veredicto de Schopenhauer 
de la desesperación, de la sed de venganza y la ambición presentados el día anterior, Segismundo pasa a aceptar su destino con la conciencia de que todo el poder y la vida en su conjunto no son más que un breve sueño. Con tal espíritu regenerado y nuevo, Segismundo declama a Clotaldo los siguientes versos estoicos:

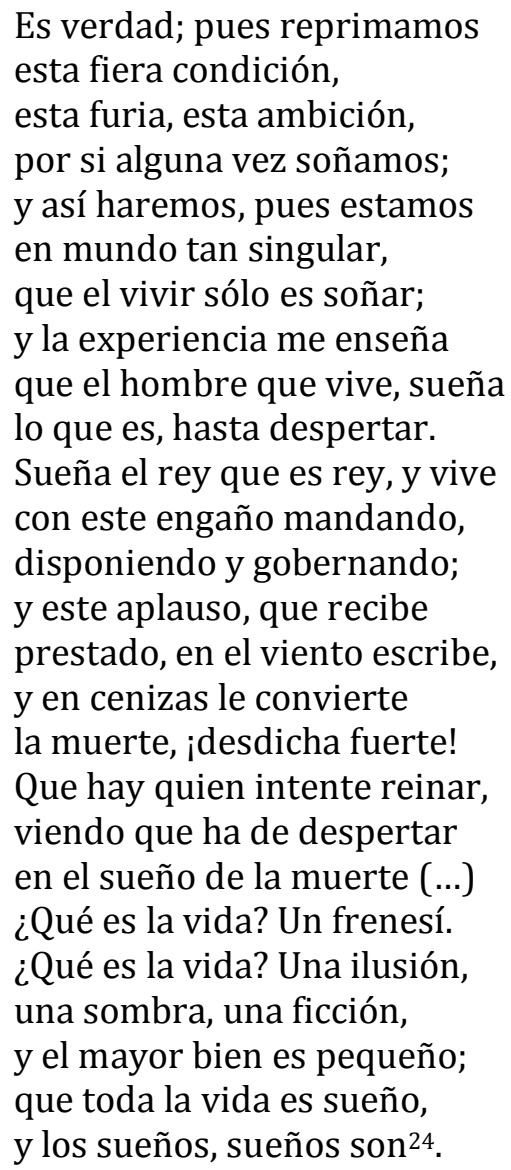

Con estas palabras se cierra la Jornada Segunda. En la Jornada Tercera, Segismundo se transforma completamente. El sufrimiento y la sed de venganza ya no le asfixian y en su lugar surge un hombre pasivo, templado y desapegado. No sería exagerado, tal vez, sospechar que de criminal o potencial criminal que era, el personaje se torna un santo o un asceta.

En las antípodas de la transformación del protagonista masculino, Rosaura mantiene su personalidad constante desde el acto anterior: es astuta y discreta, y el lector descubre su motivación: el deseo de que su antiguo prometido Astolfo, quien la abandonara para casarse con la infanta Estrella, sobrina de Basilio, aparentemente con el 
fin de heredar la corona de Polonia, reciba el castigo merecido. Además del gracioso escudero Clarín, la misión de Rosaura recibe la ayuda de Clotaldo, quien se revela ser su padre. Clotaldo cuestiona el comportamiento de Rosaura, pues lo sospecha impregnado de "despecho, desatino y frenesí"; ella, sin embargo, lo considera producto del "honor y el valor". De esta manera, si en la transformación de Segismundo Calderón expone la gracia y el perdón cristiano, que superan incluso los conceptos más básicos de justicia, castigo y deber, en la misión de Rosaura, por lo contrario, tales valores son llevados a las últimas consecuencias: en la Jornada Segunda, Rosaura usa trampas y disfraces para contaminar el compromiso por interés de Astolfo con Estrella, y en la Jornada Tercera, libera junto al pueblo, al príncipe Segismundo, acompañándolo en una insurrección contra el duque Astolfo, a punto de tornarse rey.

Hacia el final del drama, no prevalece el imperio del error e injusticia, sino algo simbolizable por el concepto schopenhaueriano de "justicia eterna": motivado por el apoyo de la bella Rosaura y del pueblo, pero sobre todo, por la convicción de que "no se pierde en hacer el bien, aún en sueño"25, Segismundo lucha contra el ambicioso Astolfo y el triste Basilio - que se había decidido a desheredar a su hijo - y los derrota heroicamente.

Al intentar evitar el destino previsto a su hijo, Basilio acaba produciéndolo, pues justamente hace del príncipe un prisionero rencoroso y vengativo. En otras palabras, al destino nada se le escapa - lo que Segismundo también repite con estos versos: "Sentencia del cielo fue; / Por más que quiso estorbarla / Él no pudo, ¿y podré yo, / Que soy menor en las canas, / En el valory en la ciencia, /Vencerla?"26. La infalibilidad del destino se mantiene casi hasta el último momento, cuando entran en escena las consecuencias de la gracia y del cambio de carácter efectuados en el príncipe luego de su percepción de que la vida es sueño: con la espada victoriosa apuntando al padre supersticioso, Segismundo lo perdona y se convierte en un rey piadoso. Así, Segismundo vence al destino terrestre, simbólicamente, "con la ayuda del cielo". Al volverse rey, perdona compasivamente al padre miedoso y al primo oportunista. Este se casa con Rosaura que es reconocida como la noble hija de Clotaldo. Clarín es muerto en la batalla, por esconderse cobardemente tras un arbusto. Y el pueblo, que exige una recompensa al rey, es mandado a la cárcel por haberse rebelado.

25 CALDERÓN DE LA BARCA, P. Ibídem. P. 95.

${ }^{26}$ CALDERÓN DE LA BARCA, P. Ibídem. P. 123.

La vida es sueño, de Calderón de la Barca - ante el tribunal de la Kallipolis y el veredicto de Schopenhauer 
Entre los diversos aspectos de la riqueza filosófica de este drama está el hecho de que lo que completó la "educación cristiana" recibida de Clotaldo en la cárcel e hizo capaz a Segismundo de volverse un héroe compasivo y estoico, y por lo tanto, un tipo de héroe distinto del héroe caballeresco tradicional, que muchas veces es movido por ambición, fue la intelección de que la vida es sueño.

En sus diálogos, personajes y desenlace, La Vida es Sueño presenta, en la forma literaria, una riqueza filosófica profunda y multifacética. Frente a tal fecundidad, cualquier comentario corre el riesgo de ser pobre o parcial. En una esforzada tentativa por no serlo, propondremos a seguir una interpretación con base en el comentario de Schopenhauer en El Mundo como Voluntad y Representación (1818).

En el Libro I de su obra magna, Schopenhauer afirma que La Vida es Sueño, de Calderón, puede ser entendida como un "drama metafísico"27 en la medida en que expone, entre otras cosas, la visión más importante de su teoría de la representación o epistemología: el idealismo. Para Schopenhauer, el idealismo filosófico se basa en la siguiente sentencia: "El mundo es mi representación (Vorstellung)”28. Según tal doctrina, la realidad es inevitablemente el producto de la mente del sujeto cognoscente. En las sintéticas palabras de Berkeley - dice Schopenhauer - "Ningún objeto sin sujeto"29. Es decir: no hay ni puede haber un objeto sin sujeto. El sujeto es el "sustentáculo del mundo, la condición universal y siempre presupuesta de todo lo que aparece, de todo objeto, pues todo lo que existe, existe para el sujeto"30. Como el sujeto es siempre presupuesto por detrás del conocimiento de todo objeto, Schopenhauer lo define como "aquel que todo conoce pero no es conocido por nadie"31. Al final, si algo es conocido, es conocido como un objeto para un sujeto, de manera que el sujeto jamás puede ser conocido propiamente, sino solamente presupuesto o inferido a partir del objeto. Ambos, sujeto y objeto, delimitan, para el filósofo, la frontera a priori de todo el mundo como representación; ellos son, precisamente, las dos mitades formales del mundo, "inseparables, incluso para el

\footnotetext{
27 SCHOPENHAUER, A. WWV. P. 50.

28 SCHOPENHAUER, A. Ibídem. P. 31.

29 SCHOPENHAUER, A. KK. P. 546.

30 SCHOPENHAUER, A. MVR. P. 45

31 SCHOPENHAUER, A. Ibídem

La vida es sueño, de Calderón de la Barca - ante el tribunal de la Kallipolis y el veredicto de Schopenhauer
} 
pensamiento: cada una posee significación y existencia apenas por y para el otro; cada una existe con la otra y desaparece con ella. Ellas se limitan inmediatamente: donde comienza el objeto, termina el sujeto"32. Como esa comunión define las condiciones formales y a priori más generales del mundo como representación, que se desarrolla en el espacio y tiempo, lleno de la materia y movido por la causalidad, Schopenhauer afirma que ese nuestro mundo está inevitablemente marcado por el "sello de la idealidad"33. Ninguna filosofía después de Kant - escribe el discípulo - puede evadir el idealismo transcendental kantiano. Este idealismo trasciende el idealismo de Berkeley, porque no solo enuncia la idealidad de la realidad objetiva, sino que demuestra nuestra capacidad de conocer las condiciones a priori del objeto, es decir, sus formas universales y necesarias, en base al examen de las propiedades formales y cognitivas del sujeto. Aunque haya dado ese paso en relación a Berkeley, Schopenhauer prefiere simplificar la deducción kantiana de las propiedades transcendentales de toda experiencia posible, básicamente, con la expresión del principium individuationis, compuesto por el tiempo, el espacio y la causalidad o materia. Por otro lado, el principium individuationis se subordina a la forma a priori más universal mencionada anteriormente, expresada en la sentencia "el mundo es mi representación". De acuerdo con el pensador, ninguna certeza es más simple, "cierta, independiente de todas las otras y menos necesitada de una prueba (...) inclusive cuando ella no sea una proposición que cualquier uno entiende inmediatamente al escucharla" 34 . Tal incomprensibilidad, para el filósofo, se debe a que, por un lado, las tres religiones monoteístas - el judaísmo, cristianismo y islamismo - han difundido la concepción opuesta y absurda según la cual el mundo fuera de nuestra representación existe de una manera absoluta y idéntica a como está en ella, sin que la representación ponga nada de su propia formalidad; por otro lado, el idealismo transcendental también es inaceptable completamente porque siempre exige el complemento metafísico, basado en una perspectiva "toto genere" distinta de la representación, según la cual el mundo también es algo en sí mismo a lo que nos acercamos de la manera más inmediata en nuestra autoexperiencia como una fuerza vital o voluntad.

En lo que concierne aún al idealismo transcendental, Schopenhauer aclara además que de modo alguno esa visión niega la realidad empírica del mundo externo, como lo hace

32 SCHOPENHAUER, A. Ibídem.

33 SCHOPENHAUER, A. $W W V$. P. 12.

34 SCHOPENHAUER, A. $W W V$. P. 11.

La vida es sueño, de Calderón de la Barca - ante el tribunal de la Kallipolis y el veredicto de Schopenhauer 
por ejemplo el idealismo empírico o absoluto de Fichte o Jacobi. Según el filósofo, el idealismo transcendental "deja la realidad empírica del mundo intocada, pero se atiene únicamente al hecho de que todo objeto y, así, la realidad empírica en general, es condicionado por el sujeto"35. Al mismo tiempo, Schopenhauer también reconoce que el hecho de que el mundo sea producto de una función mental lo torna, "al menos en un aspecto, parecido o inclusive pasible de ser puesto en la misma clase que un sueño"36. Más específicamente, el filósofo entiende que el mundo del sueño y de la vigilia se distinguen solo por su materia o contenido, mientras son "obviamente moldados a partir de una misma forma": la función intelectual. Según el pensador, la sabiduría hindú reconoce esta semejanza formal entre la vigilia y el sueño con su mito del velo de Maya, según el cual el mundo material es comprendido como "un efecto mágico (...), una apariencia inconstante y no esencial, en sí destituida de ser, comparable a la ilusión de óptica y al sueño, un velo que envuelve a la consciencia humana, un algo del que es igualmente falso y verdadero decir que es, o que no es"37. Junto al hinduismo, también Platón, para Schopenhauer, enseña que "el mundo que aparece a los sentidos no posee verdadero ser, sino solamente un incesante devenir; él es, y también no es; su aprehensión no es tanto un conocimiento como una ilusión" 38 , ya que sus constituyentes se transforman en lo opuesto con facilidad y rapidez. Píndaro también entendió esa consecuencia del idealismo cuando engendró los versos: " $\sigma \chi \iota \alpha \varsigma$ ov $\alpha \rho \alpha \nu \theta \rho \omega \pi$ ऽ (el hombre es el sueño de una sombra)". Y de una manera no menos genial y artística, Calderón de la Barca penetró y exploró esa visión filosófica y mítica en su drama, exponiendo, ya en el título, exactamente el mismo insight: La Vida es Sueño. Ese homenaje a la fecunda obra del barroco español fue hecho, por vez primera, en El Mundo..., con las siguientes palabras: “Calderón estaba tan profundamente imbuido de esa visión [el idealismo], que buscó expresarla, por así decirlo, en un drama metafísico, titulado La Vida es Sueño"39.

Considerando el resumen anterior de la trama de la obra, vemos claramente que el vínculo que Schopenhauer hace entre ella y el idealismo es perfectamente adecuado. En efecto, en el drama calderoniano, la intelección de la cualidad onírica de la realidad alcanzada por Segismundo es lo que lo libra del sufrimiento y lo cubre de un aspecto

\footnotetext{
35 SCHOPENHAUER, A. Ídem. P. 17.

36 SCHOPENHAUER, A. Ídem. P. 12.

37 SCHOPENHAUER, A. KK. P. 567.

38 SCHOPENHAUER, A. Ídem. P. 566.

39 SCHOPENHAUER, A. WWV. P. 50.

La vida es sueño, de Calderón de la Barca - ante el tribunal de la Kallipolis y el veredicto de Schopenhauer
} 
piadoso y resignado, que va más allá de la venganza y de la conquista y trae, así, un nuevo ambiente completamente renovado a la segunda fase de la obra. Que la cumbre de la proximidad entre los versos declamados por Segismundo y el discurso del idealismo ocurra en la transición de la Jornada Segunda es extremamente sugestivo. La transición de la jornada está en sintonía con el cambio de disposición, o incluso de carácter del príncipe Segismundo, que es lo que antecede, en todos los sentidos, su triunfo y coronamiento político, que tienen lugar integralmente en la Jornada final. En clave schopenhaueriana, podría decirse que ese coronamiento político, terrestre y por lo tanto no del todo libre de ser comparado a un sueño, no es sino un símbolo que sella la conversión y purificación moral del príncipe, la cual a su vez se basa en la comprensión de que la vida es sueño. Como la sabiduría epistemológica, sin embargo, no es suficiente para explicar la regeneración de Segismundo, sino que ésta pide por un complemento ético, Schopenhauer se siente motivado a rescatar la referencia a La vida es sueño en El Mundo... en otros dos momentos distintos - uno en su metafísica de lo bello y otro en la metafísica de las costumbres (Libros III y IV respectivamente). Examinemos esas otras noticias, por lo tanto, procurando ahondar, mediante ellas, la comprensión del destino de Segismundo.

\section{V}

En el Libro III de El Mundo..., Schopenhauer defiende que la tragedia y el drama son el ápice del arte poético, "tanto en lo que respecta a la magnitud de sus efectos como a la dificultad de sus realizaciones" 40 . Para el filósofo alemán, el gran logro de la poesía trágica y dramática es revelar el "lado terrible de la vida; es decir, el innombrable sufrimiento, la miseria humana, el triunfo del mal, el imperio cínico del azar, la caída inevitable de lo justo y lo inocente" 41 , etc. Por esta revelación, el pensador entiende que, sobre todo la tragedia, ofrece una "indicación muy significativa de la índole del mundo y de la existencia", pues expone que en la esencia de la naturaleza yace una incesante (auto)discordia entre los fenómenos, una gula abisal que intenta aplacar un igualmente hondo vacío, todo lo cual deriva en un sufrimiento agudo y originario. Según la doctrina schopenhaueriana, la tragedia y el drama exponen el grado más crítico en el que el dolor se presenta en la

40 SCHOPENHAUER, A. $W W V$. P. 354.

41 SCHOPENHAUER, A. Ídem. P. 355.

La vida es sueño, de Calderón de la Barca - ante el tribunal de la Kallipolis y el veredicto de Schopenhauer 
naturaleza: aquel que afecta al hombre. La gran poesía - afirma el filósofo - en el ápice de su exposición, manifiesta el momento en el que la "rueda de Íxion" para de girar, cuando sus héroes:

Purificados y ennoblecidos por el sufrimiento, llegan al punto en que el fenómeno, el Velo de Maya, no los afecta más. Ellos ven a través de la forma del fenómeno, del principium individuationis [tiempo, espacio y causalidad], con lo que también expira el egoísmo. Con esto, los motivos hasta entonces poderosos pierden su poder $\mathrm{y}$, en su lugar, el conocimiento perfecto de la esencia del mundo, actuando como paliativo de la Voluntad, produce la resignación, la renuncia, no solamente de la vida, sino de toda la Voluntad misma. Así, vemos al fin de la tragedia a los más nobles, después de una larga lucha y sufrimiento, desistiendo de los fines hasta entonces perseguidos vehementemente, y abdicando para siempre de todos los goces de la vida, librándose de estos con alegría, como hizo el príncipe constante de Calderón, o Gretchen en Fausto, o Hamlet 42 .

Así, en su segunda referencia a Calderón en El Mundo..., Schopenhauer se refiere al "príncipe constante" como exponente trágico o dramático de lo que él llama autonegación de la Voluntad de vivir. Aunque Calderón haya escrito una tragedia titulada El Príncipe Constante (1629, 1636), Schopenhauer no cita ese libro en mayúsculas e itálicas, probablemente, para no limitar su referencia a esa figura trágica específica de El Príncipe Constante, permitiendo que ella sea extendida a otros "príncipes constantes" de la obra calderoniana. En El Príncipe Constante, el protagonista y rey Fernando de Portugal experimenta la autodiscordia y autonegación de la Voluntad en un grado muy elevado: luego de caer en cautiverio en las manos de sus enemigos marroquíes, el rey sufre las más diversas formas de torturas, negando ascéticamente las oportunidades que surgen de cambiar su dolor por la libertad (una, cuando esa es ofrecida a él por el precio de su conversión al islamismo, y otra, por el precio de su donación de la ciudad de Ceuta). En este punto se plantea la cuestión de si la referencia al "príncipe constante de Calderón" se extiende también a Segismundo de La Vida es Sueño y, caso sí, cuáles elementos de la nueva apreciación de Schopenhauer pueden iluminar nuestra interpretación de ese drama. Atendamos más detenidamente, pues, a la concepción del filósofo en relación al ápice del arte literario, es decir, la tragedia. 
Schopenhauer defiende que el tema universal de la tragedia no puede ser la "lucha [del hombre] contra el destino", lo que solo podría ser una lucha contra un enemigo invencible ${ }^{43}$. Para él, el tema universal de la tragedia es la exposición del sufrimiento estructural del hombre, lo que puede ser logrado en base a tres estrategias distintas, cada una de las cuales define un grado distinto de excelencia trágico-literaria. Dichas estrategias dicen respecto a la causa del sufrimiento expuesto, la cual puede (i) estar condensada en un personaje dotado de una "maldad extraordinaria, que roce los límites de la veracidad", como en Otelo y El Mercader de Venecia, de Shakespeare, o Antígona, de Sófocles; (ii) ser el "destino ciego, el azar o el error", como en la "mayoría das tragedias de los antiguos", en Romeo y Julieta, de Shakespeare, etc.; por último, la causa del sufrimiento puede (iii) radicar en "la mera disposición mutua de las personas y en las combinaciones de sus relaciones recíprocas", de tal modo que "las personas sean de tal manera opuestas que precisamente su situación las compela concienzudamente a tramar la mayor desgracia unas contra las otras, sin que con eso la injusticia sea atribuida sencillamente a un solo lado"44. Según Schopenhauer, este último género de tragedia es el más perfecto, desde que expone el dolor "no como excepción, sino como algo que proviene fácil y espontáneamente de las acciones y los caracteres humanos, como una cosa casi esencial, terriblemente innata en nosotros" 45 . Ejemplos de esas obras son, para el autor, Clavigo y Fausto, de Göthe, Wallenstein, de Schiller, Cid, de Corneille, y Hamlet, de Shakespeare. En cuanto al significado último de la poesía trágica, el alemán lo encuentra, precisamente, en los versos mencionados con los cuales Calderón exprime la agonía de Segismundo en $L a$ Vida es Sueño. Dice Schopenhauer:

El sentido verdadero de la tragedia se encuentra en la intelección profunda de que los héroes no expían sus pecados individuales, sino el pecado original, es decir, la culpa de la existencia misma: 'Pues el delito mayor/ Del hombre es haber nacido', como Calderón exprime con franqueza ${ }^{46}$.

Así, en su tercera referencia a Calderón en El Mundo..., Schopenhauer defiende la interpretación de que los versos de La Vida es Sueño expresan el "sentido verdadero" de

\begin{tabular}{l}
43 SCHOPENHAUER, A. P/P. P. 437. \\
44 SCHOPENHAUER, A. WWV. P. 356. \\
45 SCHOPENHAUER, A. Ídem. \\
46 SCHOPENHAUER, A. Ídem. P. 355. \\
\hline La vida es sueño, de Calderón de la Barca - ante el tribunal de la Kallipolis y el veredicto de Schopenhauer
\end{tabular} 
la poesía trágica y exprimen, además, el mito cristiano del pecado original. Según el filósofo, la esencia trágica está en la exposición del sufrimiento humano, y dichos versos de Segismundo, que hacen referencia al mito bíblico del pecado original, aclararan precisamente el origen de este infortunio: se sufre porque se nace y se vive, y nacer y vivir implican inmediatamente una gran e inevitable inmoralidad (en tanto egoísmo y búsqueda de poder) a la que viene anexa el castigo inmediato de la carencia incesante, la necesidad y el dolor.

En el Libro III de El Mundo, Schopenhauer no se extiende más allá de esta referencia, puesto que el objeto de investigación en este libro es el mundo en tanto arte y belleza. Solamente en el Libro IV, que concierne a la metafísica de las costumbres, el pensador se propondrá investigar la fuente de ese delito (la inmoralidad) y su castigo (el sufrimiento) humano, llamado por él "justicia eterna". Como los versos de La Vida es Sueño, al menos conforme a su lectura, tienen un espíritu vivamente ético-metafísico, será en esta última sección de su obra magna que Schopenhauer llevará la interpretación de La Vida es Sueño hasta las últimas consecuencias. Antes de eso, cabe decidir si La Vida es Sueño es una tragedia, un drama o una comedia, en base a los conceptos presentados anteriormente.

El Príncipe Constante, de Calderón, representa sin duda la forma más definida del género trágico para Schopenhauer; sin embargo, La Vida es Sueño no se distancia de El Príncipe..., pues expone las peripecias de un personaje muy semejante a Fernando de Portugal. Mientras en El Príncipe Constante la gloria del protagonista es sucedida por su fracaso, ascetismo y muerte - lo que expone un tema mucho más real que su revés - en $L a$ vida es sueño, la excepción es expuesta por medio de un príncipe cuyo sufrimiento precede a la purificación, la liberación y la gloria. Ya que la contemplación de ese último movimiento es más agradable y menos frecuente en la realidad (al menos desde la perspectiva schopenhaueriana) hay quien defina La Vida es Sueño como una comedia. No parece tal ser el caso, sin embargo, puesto que la comedia abunda en caricatura y burla, mientras en La Vida es Sueño esos dos recursos son escasos, limitados a la discreta participación del escudero Clarín. En lugar de eso, Schopenhauer parece acertar cuando define La Vida es Sueño como un "drama metafísico". Más cercano de la tragedia de que de la comedia, no obstante, la obra no se deja definir como una tragedia stricto sensu, dado que en su desenlace predomina lo más improbable: la más plena consumación de la justicia entendida temporalmente, bien como el alcance de objetivos de los justos, y el fracaso de 
los objetivos de los ávidos. Schopenhauer parece estar en lo correcto cuando defiende que la única justicia infalible en nuestro mundo es la justicia eterna, que debe ser comprendida de modo completamente atemporal e inmediato.

\section{VI}

En el Libro IV de El Mundo..., que presenta lo esencial de su metafísica de las costumbres, Schopenhauer cita nuevamente los mencionados versos de Segismundo. En este caso, sin embargo, lo hace en un contexto más propicio a la comprensión del contenido moral y metafísico de dichos versos. El párrafo en el que ocurre esta tercera referencia (§63) se dedica a la exposición del concepto de la "justicia eterna", al cual el pensador relaciona el sentido último de los versos calderonianos. Analicemos más detenidamente tal concepto.

Schopenhauer afirma que el concepto de justicia eterna denota el hecho moral de que "el mundo es el tribunal del mundo"47. En otras palabras, la responsabilidad por el destino y la índole moral del mundo o del hombre pertenece solamente al propio mundo. Al final - cuestiona el pensador: ¿cómo algo externo podría asumir esa responsabilidad? De modo íntimamente conectado con eso, el filósofo defiende que el destino y la índole moral del mundo son completamente equivalentes, es decir: ambos son una única y misma cosa. Tal como sea la inmoralidad universal - alega el pensador - así será la infelicidad universal, y viceversa ${ }^{48}$. La conclusión inevitable a cual llega Schopenhauer es que no hay en el sufrimiento injusticia alguna, sino que al hombre, pensado en tanto Idea eterna y universal, le sucede exactamente lo que le corresponde moralmente (o le corresponde exactamente lo que le sucede) de la manera más inmediata. Con las siguientes palabras, Schopenhauer exprime su concepto de justicia eterna que, según su comprensión, rige el mundo de modo infalible:

La responsabilidad por la existencia y la índole de este mundo solamente puede asumirla el propio mundo, nadie más, pues ¿cómo algo externo podría asumirla? - Si uno quiere saber, en términos morales, lo que valen

\footnotetext{
47 SCHOPENHAUER, A. Ídem, p. 482.

48 Básicamente, el filósofo entiende por inmoral todo acto de egoísmo invasivo o de pura maldad. En el primer grupo, él afirma que están la "avidez, glotonería, intemperancia, codicia, dureza de corazón, orgullo, vanidad, etc.", y en el segundo, los "celos, envidia, curiosidad indiscreta, maldad, insolencia, petulancia, ira, tradición, rencor, espíritu vengativo, crueldad, odio” (SCHOPENHAUER, A. E/E. P. 732).

La vida es sueño, de Calderón de la Barca - ante el tribunal de la Kallipolis y el veredicto de Schopenhauer
} 
los hombres como un todo y en general, considérese su destino como un todo y en general: carencia, miseria, penuria, tormento y muerte. La justicia eterna prevalece. Si los hombres, en su conjunto, no fueran tan indignos, entonces su destino, también en su conjunto, no sería tan triste. En este sentido, podemos decir: el propio mundo es el tribunal del mundo. Si pudiera ponerse toda la miseria del mundo en un platillo de la balanza y toda la culpa en el otro, el fiel permanecería en el medio ${ }^{49}$.

De acuerdo con Schopenhauer, en la justicia legal y temporal humana, crimen y castigo son eventos distintos; aquí se comete un delito, allí viene el castigo. En la justicia eterna, sin embargo, crimen y castigo se dan concomitantemente y en la más intrínseca ligazón: según sea la injuria y por lo tanto la inmoralidad, inmediatamente y en la misma medida será el sufrimiento, en tanto castigo - y a la inversa. Según esta doctrina, solo el conocimiento limitado al principium individuationis (es decir, al tiempo, el espacio y la causalidad) logra mirar el castigo por un lado y el crimen por el otro; la miseria aquí, el goce allí; la maldad en este individuo, el padecimiento en aquel. La persona que limita su visión a las categorías del principium individuationis es invadida por la irresistible pregunta: ¿Dónde encontrar retaliación para todo el dolor? Así, ese individuo observa el sufrimiento universal como algo completamente extraño, pues solamente "su persona que desaparece, su presente sin extensión, su gratificación momentánea" poseen realidad 50 . Tal individuo se lanza "a las orgías y a los goces de la vida, los abraza firmemente, y no sabe que, precisamente por dichos actos de su voluntad, toma y sujeta a sí firmemente los dolores y los tormentos de la vida, cuya visión tanto lo aterroriza"51. Sin embargo, Schopenhauer advierte que "en la profundidad más interior de su consciencia [ese sujeto] experimenta el sentimiento oscuro de que quizá" todo el sufrimiento, dividido y multiplicado en inúmeros seres vivos a partir del principium individuationis, "no le sea totalmente extraño, sino que tiene relación con él, de la cual el principium individuationis no puede protegerlo"52. Ese "sentimiento oscuro" - argumenta el autor - se eleva a un verdadero asombro cuando la regularidad de la experiencia del principium individuationis falla particularmente, y entonces "algún acontecimiento se da sin causa (...), de alguna manera lo ya acontecido o el futuro se tornan presentes, o lo distante se aproxima", etc. Para Schopenhauer, también los sentimientos morales producidos en toda y cualquier

\footnotetext{
49 SCHOPENHAUER, A. $W W V$, p. 479.

50 SCHOPENHAUER, A. $W W V$, p. 481.

51 SCHOPENHAUER, A. Ídem, p. 480.

52 SCHOPENHAUER, A. Ídem, p. 481.

La vida es sueño, de Calderón de la Barca - ante el tribunal de la Kallipolis y el veredicto de Schopenhauer
} 
injusticia - tanto en el agresor como en la víctima - ponen en jaque la soberanía del principium individuationis. Sea en la mordida de consciencia (Gewissenbiss) del agresor, sea en la indignación moral de la víctima - sentimientos esos que pueden presentarse inconscientemente (unbewusst) - lo que se anuncia es que las relaciones y diferencias en el tiempo, espacio y causalidad son tan solo apariencia e ilusión. En última instancia, toda la perspectiva ética de la existencia - así como la estética y la metafísica ${ }^{53}$ - defiende Schopenhauer - se basa en la sabiduría de que la esencia del mundo y del hombre son atemporales (eternas), no-espaciales (una) y no causales (libres) ${ }^{54}$. Siendo así, todo castigo, en tanto dolor, como todo crimen, en tanto inmoralidad, se unifican en esa fuente originaria que es la Idea hombre y la Voluntad de vida. Con las siguientes palabras el pensador expresa como en todo acto de injusticia se siente, más allá del principium individuationis y tanto por quien lo perpetúa como por quien lo padece, la unidad esencial del hombre y la vida, en la cual se basa el concepto de la justicia eterna:

Quién sufre la injusticia siente la invasión (...) como un dolor inmediato, espiritual, completamente separado y distinto del sufrimiento físico infringido por el acto o del pesar provocado por la pérdida. Por otro lado, a quien practica la injusticia se le presenta por sí mismo el conocimiento de que él, en sí, es la misma Voluntad que también aparece en el otro cuerpo, afirmándose con tanta vehemencia en un único fenómeno que (...) entra en conflicto consigo mismo (...), hincando los dientes en la propia carne. A quién practica la injusticia ese conocimiento se le presenta (...) como un sentimiento oscuro, el cual se denomina mordida de consciencia (Gewissenbiss) o (...) sentimiento de injusticia cometida (ausgeübten Unrecht $)^{55}$.

Así, Schopenhauer escribe que estos indicios invitan a que los ojos sean abiertos por un conocimiento mejor que, por sobre de las "cosas particulares", "ve más allá del principium individuationis, percibe que las formas del fenómeno no conciernen a la cosa en sí" y propician, al fin y al cabo, la asimilación de que la esencia del mundo es una y regida por la justicia eterna. Según el pensador, "solo una persona así, en virtud de ese conocimiento, puede comprender la esencia verdadera de la virtud (...) aunque para la

${ }^{53}$ Cf. SCHOPENHAUER, A. Ídem. Libros II-III.

${ }^{54}$ Esa unidad de las perspectivas metafísica, estética y ética, bajo el concepto de la unidad de la Voluntad, es anunciada por el pensador en los siguientes términos: "Toda mi exposición puede ser vista como in simples desarrollo de (...) la verdad puramente teórica (...) de que la Voluntad es la cosa en sí de cada fenómeno, pero ella propia, en tanto tal, es libre de las formas del fenómeno, por tanto, también de la pluralidad" (SCHOPENHAUER, A. MVR, p. 476). 
práctica de la misma, de modo alguno ese conocimiento sea necesario en su forma abstracta" 56 .

Ese "conocimiento mejor" de la identidad del torturador y el torturado, bien como de la Voluntad y la carencia, el ultraje y el sufrimiento, son anunciados en los versos de Calderón citados por Schopenhauer por la segunda vez en El Mundo..., con las siguientes palabras:

\begin{abstract}
A aquél, por lo tanto, que alcanzó esta última forma de conocimiento, se le tornará claro que (...) el atormentador y el atormentado son uno. El primero se equivoca al creer que no participa del tormento, el segundo se equivoca al creer que no participa de la culpa. Si los ojos de ambos fuesen abiertos, quién infringe el sufrimiento reconocería que vive en todo aquello que en el vasto mundo padece tormento (...) El atormentado, a su vez, notaria que toda maldad practicada en el mundo (...) también procede de aquella misma Voluntad constituyente de su propia esencia, reconociendo mediante este fenómeno y su afirmación que él mismo asumió todo el sufrimiento procedente de la Voluntad, y todo eso con justicia, soportándolos mientras sea esa Voluntad. - De este conocimiento habla (...) Calderón en La Vida es Sueño:'Pues el delito mayor/ Del hombre es haber nacido'. ¿Cómo no sería un delito, si conforme a una ley eterna, la muerte viene después? Calderón también (...) exprimió en tales versos el dogma cristiano del pecado original ${ }^{57}$.
\end{abstract}

Esta es, pues, la última referencia de Schopenhauer a Calderón de la Barca. Como queda claro, el filósofo entiende que los versos declamados por el héroe Segismundo concuerdan con el mito cristiano del pecado original, pues expresan que la esencia humana inherente a todos y cualquier individuo, incluso al mayor de los sufridores, es el único origen de toda inmoralidad. Siendo así, por el simple hecho de afirmar la vida y vivirla, el hombre se torna responsable por toda la maldad existente, incluso aquella que existe en potencia, y también por todo el sufrimiento que viene a ser a raíz de ella. Diferentemente de la justicia temporal, que muchas veces falla, Schopenhauer afirma que la justicia eterna prevalece siempre. Así, no se debe cuestionar a este o aquel individuo que existen solo desde la perspectiva del principium individuationis - sino al hombre como tal, esto es: al hombre como Idea universal. En la medida en que el Hombre constituye el grado más alto de afirmación y complejidad de la Voluntad, él es justamente el ser más inmoral y destruidor de la naturaleza y, concomitantemente, el más necesitado, carente y sufriente. A diferencia de los demás seres vivos, el hombre, por ejemplo, sufre con el 
pasado, con el presente y con el futuro; es "querer concreto y necesidad absoluta, es una concretización de millares de necesidades"58. Innúmeras insatisfacciones lo atormentan constantemente $y$, entre ellas, la guerra de todos contra todos en un grado inigualable en toda naturaleza. Su incomparable egoísmo y maldad son la otra cara de su carencia, su dolor y su tedio.

En la tangente de esa autodiscordia volitiva, Schopenhauer amaina su pesimismo con la indicación de que aquel "conocimiento mejor"59 que se apercibe en el pecado original, es decir, el conocimiento de la identidad de los individuos y la concomitancia entre inmoralidad y sufrimiento, propicia un desapego, una renuncia y una compasión con características soteriológicas. El acto fundamental suscitado por ese "conocimiento mejor", denominado por Schopenhauer con la expresión “autonegación de la Voluntad de vivir", es lo único que puede librar al sujeto del sufrimiento existencial. En los grados intermedios en que ese pathos salvador ocurre, el autor describe que el sujeto abandona su egoísmo, siente como suyo todo sufrimiento e inmoralidad ajenos y busca disminuirlos con la práctica de la justicia y la caridad. En ese momento de genuina moralidad, tal sujeto practica la compasión, que consiste, precisamente, en la renuncia a hacer el mal al otro, o sea: en la justicia, y en la búsqueda de hacer el bien, o sea: en la caridad. En el grado más radical de la autonegación de la Voluntad, Schopenhauer distingue que el desapego en relación al mundo se vuelve tan grande que toda acción se vuelve imposible. En un estado de espíritu absolutamente pasivo, el sujeto cae en cuenta de que la vida es un frenesí y, como declama justamente el príncipe de Calderón, "una ilusión / una sombra, una ficción, / y el mayor bien es pequeño; / que toda la vida es sueño, / y los sueños, sueños son"60.

Aunque estos versos parezcan indicar solamente una posición epistemológica, a saber: la concepción del idealismo transcendental según la cual "el mundo es mi representación", el movimiento del drama La vida es sueño es prácticamente idéntico al de El Mundo...: es en plena sintonía con la sabiduría idealista que el sujeto - que, en el drama, está representado por el príncipe Segismundo - puede practicar la moralidad, que empieza con la suspensión de la perspectiva basada en el principium individuationis. Aunque inicialmente se sitúe en el primer (y negativo: "no hacer mal al otro") grado de la justicia, Segismundo extiende luego su comprensión de que la vida es sueño a la práctica

58 SCHOPENHAUER, A. Ídem, p. 428.

${ }^{59}$ SCHOPENHAUER, A. Ídem, p. 482.

60 CALDERÓN DE LA BARCA, P. La Vida es Sueño. P. 86.

La vida es sueño, de Calderón de la Barca - ante el tribunal de la Kallipolis y el veredicto de Schopenhauer 
positiva de la bondad, es decir, la caridad, cuando dice:

\author{
Levanta \\ levanta, padre, del suelo, \\ que tú has de ser norte y guía \\ de quien fie mis aciertos; \\ que ya sé que mi crianza \\ a tu mucha lealtad debo. \\ Dame los brazos. \\ CLOTALDO: ¿Qué dices? \\ SEGISMUNDO: Que estoy soñando, y que quiero \\ obrar bien, pues no se pierde \\ en hacer el bien, aún en sueño ${ }^{61}$
}

Así, es sobre todo cuando Segismundo perdona a su padre y a su primo que va más allá del grado negativo de la justicia y alcanza una nueva condición de carácter, con la práctica de la caridad: con el perdón, el príncipe no solamente se priva de hacer el mal sino que realiza una acción positiva, concediendo a sus "enemigos" la libertad. Así, más allá de la comprensión epistemológica de que el mundo es comparable a un sueño desde el punto de vista formal - en los términos de Schopenhauer -, es todavía más determinante para la transformación de carácter de Segismundo su asimilación de la justicia eterna, declamada en sus versos: "Pues el delito mayor / del hombre es haber nacido"62. Pronunciados en el inicio de la Jornada Primera, el significado cabal de esos versos se muestra lejos de haber sido realmente asimilado por Segismundo en ese momento e inclusive en la Jornada Segunda, en la cual el príncipe presenta un carácter irascible, vengativo y tiránico. Solo en la Jornada Tercera el príncipe demuestra haber comprendido el significado de la justicia eterna, cuando ya no identifica el sufrimiento con la inmoralidad de la vida en palabras, sino en actos, de tal modo que domina la ira de la Jornada Segunda y extiende hacia su padre y primo el perdón y la compasión.

La posibilidad de una transformación verdadera del carácter, sin embargo, es excepcional. Tal es así que fue descrita por el cristianismo bajo el concepto de la gracia y fundamentada por Schopenhauer en base al concepto de la libertad nouménica de la Voluntad, la cual solo es pensable en virtud de la anterioridad de dicha Voluntad al tiempo, el espacio y la causalidad. Desde la perspectiva schopenhaueriana, la transformación de la propia esencia personal solo puede ocurrir luego del más profundo autoconocimiento

61 CALDERÓN DE LA BARCA, P. Ídem. P. 95.

${ }^{62}$ CALDERÓN DE LA BARCA, Ídem, p. 13, grifo nuestro.

La vida es sueño, de Calderón de la Barca - ante el tribunal de la Kallipolis y el veredicto de Schopenhauer 
de la Voluntad, que por alguna experiencia rara e intensa asimile profundamente no solo la idealidad de la existencia sino el estatuto último de la justica eterna. Como tal asimilación es improbable (ya que el intelecto humano intuye el mundo sobre todo por medio del principium individuationis y la regeneración del carácter depende de algo anterior a él), nunca es posible afirmar con exactitud cuándo y si de hecho ella ocurre en los héroes, sea de la historia, sea de la literatura. En virtud de esa excepcionalidad, el cristianismo simboliza dicha transformación con la imagen del origen externo y "supramundano" de la gracia. Origen que, para Schopenhauer, no puede ser sino la Voluntad, de la cual el mundo es espejo y objetivación. Cabe finalmente, entonces, que el cambio de carácter de Segismundo entre la Jornada Segunda y Tercera haya sido producto de este movimiento insólito de la Voluntad.

\section{VII}

Por otro lado, es verdad que Segismundo nunca llega al grado total de autonegación de la Voluntad, es decir: nunca llega al ascetismo. El ascetismo, sin embargo, es un tema que Calderón explora en El Príncipe constante, cuya primera edición tal vez no por acaso aparece un año después de la de La vida es sueño. Según Schopenhauer, la santidad o el ascetismo consisten en la "mortificación intencional de la propia Voluntad"63, emprendida por medio del "ayuno, la castidad, el autoflagelo, a fin de, por constantes privaciones y sufrimientos, quebrar y mortificar cada vez más" 64 la fuente de todo el sufrimiento, es decir: la Voluntad de vida. Aunque Segismundo haya llegado próximo a tornarse santo o asceta, Rosaura y el pueblo polonés lo invitan a reclamar la corona que es suya por derecho y él acepa, bajo el argumento de que "no se pierde en hacer el bien, aún en sueño" 65. En el momento de tal decisión, Segismundo percibe que lo ocurrido en la Jornada Segunda ha sido verdad y no un sueño. Sin embargo, tan grande es su convicción de que la vida y la gloria son espectros pasajeros que no deja de clasificarlas como "sueños". En el discurso en el cual opta por la gloria frente al ascetismo, el príncipe reconoce la tenue distinción entre la vida-sueño y la gloria verdadera y sus "copias", es decir: el sueño en sentido estricto y la gloria sin honor. Aunque todo placer y poder sean evanescentes y, desde cierta

63 SCHOPENHAUER, A. MVR II, p. 730.

64 SCHOPENHAUER, A. MVR, p. 485

65 CALDERÓN DE LA BARCA, P. Ídem, p. 95.

La vida es sueño, de Calderón de la Barca - ante el tribunal de la Kallipolis y el veredicto de Schopenhauer 
perspectiva, ilusorios, Segismundo se abre a ellos, pues considera que no toda "vanagloria humana" es opuesta a la "gloria divina" 66 o el honor, sino tan solo aquella fundada en la mentira (duplamente onírica). En el siguiente monólogo, el príncipe se decide a no llevar la autonegación de la Voluntad hasta el grado del ascetismo, y a aceptar en su lugar la autoafirmación:

Luego fue verdad, no sueño; y si fue verdad - que es otra confusión y no menor -, ¿Cómo mi vida le nombra sueño? Pues, ¿tan parecidas a los sueños son las glorias, que las verdaderas son tenidas por mentirosas, y las fingidas por ciertas? ¡Tan poco hay de unas a otras que hay cuestión sobre saber si lo que se ve y se goza es mentira o es verdad! ¿Tan semejante es la copia al original, que hay duda en saber si es ella propia? Pues si es así, y ha de verse desvanecida entre sombras la grandeza y el poder, la majestad, y la pompa, sepamos aprovechar este rato que nos toca, pues sólo se goza en ella lo que entre sueños se goza. Rosaura está en mi poder; su hermosura el alma adora; gocemos, pues, la ocasión; el amor las leyes rompa del valor y confianza con que a mis plantas se postra. Esto es sueño; y pues lo es, soñemos dichas ahora, que después serán pesares. Mas ¡con mis razones propias vuelvo a convencerme a mí! Si es sueño, si es vanagloria, ¿quién por vanagloria humana pierde una divina gloria? 67

Así, lo que Schopenhauer define como el "último grado" de autonegación de la

66 Ibidem..

67 Ibidem.

La vida es sueño, de Calderón de la Barca - ante el tribunal de la Kallipolis y el veredicto de Schopenhauer 
Voluntad, es decir, la santidad y ascetismo, no es expuesta por Calderón en La vida es sueño. Para la descripción de ese no-acto transmundano, Schopenhauer afirma que faltan todos los conceptos, pues los conceptos son extraídos del mundo de la afirmación en el cual nos encontramos, y desde el cual solo se puede describir la autonegación como la no-actitud, la nada, o como prefieren los budistas, el Nirvana. Para el filósofo, sin embargo, esa "nada" no es absoluta, sino relativa. Es la "nada" en relación al principium individuationis, el cual, inversamente, para el Nirvana es a su vez la nada.

Según P. Deussen, el concepto budista de Nirvana se origina de "Brahma-Nirvânam (el apagarse en Brahman)" (Bhagavadgîtâ, $V, 25,26)$, siendo Brahman el todo del mundo para los hindúes ${ }^{68}$. De ese modo, la nada budista es, original y simultáneamente, también el todo; el absorberse en la totalidad del mundo, el Todo-Nada. Como enseñan los budistas, sobre la nada debemos callar. Sin ambicionar polemizar, podemos solamente recomendar la lectura de La vida es sueño y El Príncipe constante, de Calderón, como exposiciones ideales - es decir, pertenecientes al último límite de la capacidad humana de exposición de lo esencial e incomprensible, con imagines y palabras - respectivamente, de la bondad (justicia y caridad) y el ascetismo. La transición entre ambos grados de la autonegación de la Voluntad fue sintetizada por Schopenhauer con las siguientes palabras:

Si aquel Velo de Maya, el 'principium individuationis', es de tal manera retirado de los ojos de un hombre (...) se sigue automáticamente que ese hombre reconoce en todos los seres la intimidad propia, su verdadero en sí mismo, y de ese modo tiene que considerar también los sufrimientos infinitos de todos los vivientes como si fuesen suyos: así, toma para sí mismo el dolor de todo el mundo. Ningún sufrimiento le es extraño (...) Él conoce todo, aprehende su ser y encuentra el mundo entregado a un perecer constante, en un esfuerzo vano, en íntimo conflicto y sufrimiento continuo. Ve, por donde mira, a la humanidad y a los animales sufrientes. Ve un mundo que desaparece. Y todo eso le es ahora tan próximo como su propia persona. ¿Cómo podría, mediante un conocimiento tal, afirmar precisamente esta vida por constantes actos de Voluntad, exactamente de esa forma atarse cada vez más fijamente a ella y abrazarla cada vez más vigorosamente? (...) Al contrario, aquel conocimiento de la esencia de las cosas se vuelve un quietivo de toda y cualquier volición. A partir de ese momento la Voluntad efectúa un giro frente a la vida: se amarga frente a los placeres en los cuales reconoce la afirmación del querer. El hombre alcanza, entonces, el estado de la voluntaria renuncia, la resignación, la verdadera serenidad y la completa destitución de Voluntad ${ }^{69}$.

${ }^{68}$ DEUSSEN, P. Schopenhauer und die Religion. In: DEUSSEN, P. (Org.). Viertes Buch der Schopenhauer-Gesellschaft, p. 10. 
A ese grado de renuncia no llega, como hemos dicho, Segismundo de Polonia, sino Fernando de Portugal, de El Príncipe Constante y La Fortuna Adversa, atribuida a Lope de Vega. De acuerdo a Schopenhauer, la lección de que el mundo es un valle de lágrimas y de que, consecuentemente, solo puede accederse a la salvación por la compasión (justicia y caridad) y el ascetismo, compone la esencia de las tres grandes religiones pesimistas: el cristianismo, el budismo y el brahmanismo. En ellas, el autor enseña que el camino de la purificación tiene como presupuesto la comprensión profunda e inmediata de la justicia eterna (o sea, la completa identidad entre la inmoralidad y el sufrimiento en el mundo). Según el filósofo, el cristianismo enseña ese concepto con el mito del pecado original, es decir, la alegoría según la cual Adán y Eva, representantes de la "Idea hombre", fueron responsables por todo el delito y el sufrimiento. En esa misma línea, Schopenhauer entiende que el budismo y el brahmanismo también diseminan la comprensión de la justicia eterna de muchas maneras distintas, pero en especial con la lección de "hacer desfilar delante del aprendiz todos los seres del mundo, vivos o no vivos, sobre cada uno de los cuales es pronunciada la palabra (...) tat twan asi, 'esto eres tú'"70. Esa lección directa y categórica, sin embargo, es reservada solamente a las castas superiores; las inferiores reciben una versión indirecta, sustituta, mítica y adaptada a la conducta, que es el mito de la transmigración de las almas. Según este mito, "todos los sufrimientos infringidos en vida por el hombre a otros seres son expiados en una vida posterior y precisamente por los mismos sufrimientos"71, mientras la bondad es honrada con un renacimiento más noble, o hasta con la "recompensa suprema" de no volver a renacer (el Nirvana). Para Schopenhauer, no existe ninguna doctrina religiosa que se aproxime más al concepto filosófico de la justicia eterna que la expresa por ese mito oriental. En Occidente, tal teoría surgió primero con Pitágoras y Platón, y después, fue expuesta categóricamente por su propia filosofía (la de Schopenhauer), bajo el concepto de la justicia eterna. Si tuviéramos que apuntar una versión poética íntimamente concordante con esta tesis filosófica, y que además exponga con maestría su relación con el idealismo, ella ciertamente seria La Vida es Sueño, de Calderón. En lo que respeta al budismo, los historiadores sugieren que ese drama probablemente recibió la influencia de esa religión, puesto que ella fue conocida por los españoles, aproximadamente, dos siglos antes que 
por los alemanes. Así, la influencia del budismo sobre la filosofía centroeuropea puede ser más antigua, y proveniente de una fuente más meridional y estética de lo que habitualmente se considera: la dramaturgia española.

\section{VIII}

En Senilia, Schopenhauer afirma que “todo pensar originario se da en imágenes"72; y que, "por eso, la imaginación es un instrumento tan necesario del pensamiento", de modo que "los hombres sin imaginación nunca obtendrán grandes logros, sino en la matemática"73. Conforme el filósofo, la poesía no es el arte de la palabra, sino de la imaginación, puesto que, diferentemente de las otras artes, que exponen las Ideas eternas directamente en representaciones intuitivas (visuales, sonoras, etc.), la poesía parte de conceptos, "y el paso siguiente es ir del concepto a la intuición, cuya exposición debe ser ejecutada en la fantasía del oyente"74. Para al autor, el concepto, en sí, es siempre abstracto, discursivo, racional, atado a la palabra, "completamente indeterminado en el interior de su esfera, determinable apenas según sus límites” y “enteramente agotable en su definición"75. Las Ideas eternas, cuya exposición toda arte intenta, ya es intuitiva, inmediata, y a pesar de abarcar una infinidad de fenómenos en sí, es enteramente determinada. La Idea es la universalia o unitas ante rem (el universal o la unidad antes de las cosas), mientras los conceptos son la universalia o unitas pos rem (el universal o la unidad después de las cosas $)^{76}$. La Idea es conocida por el puro sujeto del conocimiento, que se eleva sobre los intereses volitivos e intuye, en un objeto determinado, su arquetipo o "elemento puramente objetivo". Según el autor, el puro sujeto conoce, en toda y cualquier belleza, la "expresión completa de la esencia" del objeto contemplado, independiente de todas las relaciones, o incluso, en "la suma (...) el punto raíz de todas sus relaciones"77. El concepto, por su vez, es producido por la razón con la eliminación de la riqueza intuitiva de los objetos y su consecuente subordinación a la palabra, su denominador común. Consecuentemente, la Idea "desarrolla en quien la aprehende representaciones nuevas en

\footnotetext{
72 SCHOPENHAUER, A. Senilia. P. 65,3.

73 SCHOPENHAUER, A. Senilia. P. 65,3.

${ }^{74}$ SCHOPENHAUER, A. MVR, p. 317.

75 SCHOPENHAUER, A. $W W V$, p. 328. MVR, p. 310.

76 SCHOPENHAUER, A. WWV II, p. 472.

77 SCHOPENHAUER, A. WWV II, p. 470.

La vida es sueño, de Calderón de la Barca - ante el tribunal de la Kallipolis y el veredicto de Schopenhauer
} 
relación al concepto que le es homónimo: ella se asemeja a un organismo vivo, desenvolviéndose a sí mismo, dotado de fuerza de procreación, y que produce lo que no estaba allí contenido"78; el concepto, sin embargo, parece un "receptáculo muerto en el cual lo que se pone queda efectivamente lado a lado y del cual, sin embargo, nada puede ser retirado (por juicio analítico) sino lo que en él se puso (por reflexión sintética)”. Por su maleabilidad y portabilidad, Schopenhauer describe que los conceptos son útiles a la vida práctica y a las ciencias. No obstante, su carencia de "perceptibilidad y, así, 'definibilidad' y 'distinguibilidad' generales"79 lo impiden de "conceder vida interior propia a una obra"80; de modo que el concepto es infructífero en el arte. Solamente la poesía logra extractar la contemplación de las Ideas eternas - es decir, de los aspectos más esenciales del hombre y del mundo - de los conceptos. Ella obtiene ese resultado apenas con la remisión del concepto al mundo intuitivo en la fantasía del lector, lo que, para el filósofo, depende de las cualidades estéticas de la poesía, como la composición por conceptos, la construcción intuitiva de lo expuesto, la inherencia y la brevedad de la expresión ${ }^{81}$.

Por ser un arte imaginativo, Schopenhauer también defiende que la poesía tiene la

78 SCHOPENHAUER, A. $W W V$, p. 230. MVR, p. 311.
${ }^{79}$ SCHOPENHAUER, A. $W W V I I$, p. 472.
${ }^{80}$ SCHOPENHAUER, A. $W W V$, p. $330 . M V R$, p. 313.

81 Según Schopenhauer, la composición por conceptos consiste en la exploración de la intersección de dos o más conceptos, en la medida en que uno de ellos es cortado por el otro, que a pesar de disminuir su extensión, lo conduce a la riqueza intuitiva. Por ejemplo, en Homero: "Afrodita se chama ' $\varphi \iota \lambda o \mu \mu \varepsilon ı \delta \eta s^{\prime}$ ', la que se

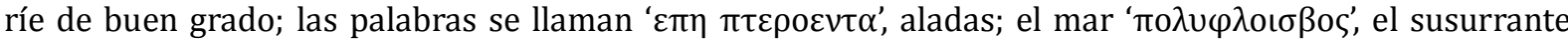
bravo; la Tierra se chama ' $\rceil \eta \delta \omega \rho \circ \varsigma \alpha \rho o u \rho \alpha$ ', la que da la vida, a todos alimentando; la muerte ' $\theta \alpha v \alpha \tau o \varsigma \tau \alpha-$ $\nu \eta \lambda \varepsilon \gamma \eta s^{\prime}$, la que distiende lentamente, los dioses se llaman ' $\rho \varepsilon \iota \alpha \zeta \omega o v \tau \varepsilon \varsigma^{\prime}$, los que viven fácilmente, sin es-

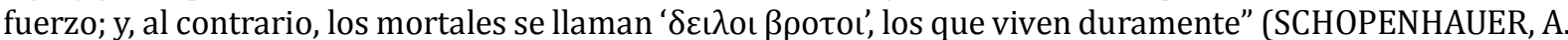
Metafísica do Belo, p. 195). La construcción intuitiva del expuesto consiste en la narración y descripción vívida, "colorida" y determinada de las ocurrencias y personajes literarios. Por ejemplo, Göthe no escribe simplemente "anocheció", sino: "El atardecer ya embalaba la tierra / Y en las montañas pendía la noche / Ya vestido de neblina estaba el roble, / Un gigante robusto, allá / En los arbustos, de donde la oscuridad / Con cien ojos negros fijaba" (GÖTHE. Apud SCHOPENHAUER, A. Metafísica do Belo, p. 196). La inherencia y propiedad de expresión, "proprietas verborum", denota el "acierto en la designación", o sea, la aprensión verbal de lo específico, de la esencia íntima de la cosa, y su expresión sin "interferencia de lo casual e lo no esencial". Mientras los poetas medianos "palpan entre millares de palabras e imágenes, acumulan expresiones, y sin embargo, no encuentran el termo correcto", el gran poeta evita la vacuidad de las expresiones comunes, cuña cada palabra con su propio estilo y expresa toda la cosa "con una única palabra". Por ejemplo, los celos de Thersites ante la pasión de Cressida e Diomedes, en Troilus and Cressida, es descrita por Shakespeare por medio del siguiente murmurio de Thersites: "Como el demonio da lujuria, con su vientre gordo y dedos / De batata, mima esos dos" (SHAKESPEARE. Apud SCHOPENHAUER, A. Metafísica do Belo, p. 194-202). Finalmente, la brevedad de expresión connota el cuidado con la economía de las palabras y la elección de pocos conceptos, "que despierten, empero, muchas y vivaces imágenes intuitivas". Por ejemplo, apenas tres palabras son necesarias para Sófocles exprimir "el fatalismo entero, el someterse al destino

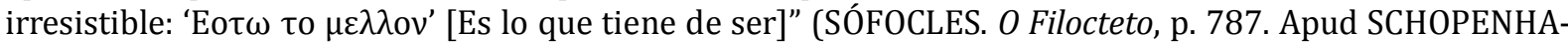
UER, A. Metafísica do Belo, p. 194-202).

La vida es sueño, de Calderón de la Barca - ante el tribunal de la Kallipolis y el veredicto de Schopenhauer 
ventaja de adecuarse "a cada uno en conformidad con su individualidad y su esfera de conocimiento, su formación y su humor"82. Otro privilegio de la poesía es el de que, en ella, una serie de pensamientos no concretos pueden ser traídos a la intuición por medio de una "metáfora, comparación, parábola o alegoría, las cuales se diferencian entre sí solamente por la extensión y por el detalle de la exposición"83. Según el filósofo, "una alegoría consiste en una obra de arte que significa algo otro que lo expuesto en ella"84, y por lo tanto constituye, fuera de la poesía, siempre una pérdida. Al final, tomemos el ejemplo de las artes plásticas: la pintura de un pez como símbolo alegórico del cristianismo no ofrece nada que el simple concepto de "cristianismo" no ofrezca, de hecho, de un modo más directo y económico. Pues no hay nada en un pez que contribuya, intuitivamente, al conocimiento del cristianismo. Un efecto infinitamente superior, y por lo tanto estético, en lo que toca a la facilitación de ese conocimiento se refiere, es ejercido, según Schopenhauer, por las obras de Rafael y Correggio, por ejemplo, que traen a la intuición, directa e ricamente, el espíritu propiamente dicho del cristianismo, es decir "el [espíritu] ético (...), por medio de la exposición de hombres plenos de ese espíritu"85. En la poesía, al contrario, las "metáforas, comparaciones, parábolas y alegorías" encuentran su verdadero dominio, justamente porque conducen del concepto, es decir, el punto de partida inevitable de ese arte, a la Idea intuitiva.

Así, si Platón tiene razón al detectar la existencia de las ideas eternas en el mundo, Schopenhauer cree haber dado un paso adelante al indicar que el arte genuino del genio es el principal medio facilitador, creado por el hombre en el campo conceptual, para la intuición de los arquetipos esenciales de la naturaleza.

\section{IX}

Para concluir, retomemos la reflexión del comienzo, esto es: la "cuestión platónica". Dice el antiguo, ahora en las Leyes:

\footnotetext{
82 SCHOPENHAUER, A. Metafísica do Belo, p. 202.

83 SCHOPENHAUER, A. Ibídem.

84 SCHOPENHAUER, A. $W W V$, p. 332. $M V R$, p. 314.

85 SCHOPENHAUER, A. MVR, p. 309.

La vida es sueño, de Calderón de la Barca - ante el tribunal de la Kallipolis y el veredicto de Schopenhauer
} 
En cuanto a los poetas serios [...] que entre nosotros se dedican a la tragedia, si alguna vez se nos presentaran e hicieran [...] la siguiente pregunta: "Huéspedes, ¿nos dais vuestro permiso para visitar vuestra ciudad y vuestro país, o no? ¿Podemos ir y traer poesías, o qué habréis decidido hacer con respecto a esto?" ¿Qué justa respuesta les daríamos a estos divinos varones? Yo creo que la respuesta sería: "Distinguidísimos huéspedes [...] nosotros mismos somos compositores de tragedias, la más hermosa y noble que haber pudiera, y siendo así, todo nuestro sistema político constituye una imitación de la vida más bella y noble, lo que en nuestra opinión viene a ser la tragedia más auténtica. Vosotros sois, efectivamente, poetas; pero también lo somos nosotros, y de la misma poesía [...] (y) vuestros competidores y adversarios en el arte del más bello drama, cuya representación solo la auténtica ley tiene capacidad natural de llevar a cabo. De modo que no os creáis que vamos a permitir tan fácilmente que levantéis un escenario en nuestra plaza y que nos presentéis actores de hermosa voz [...] ni que os autoricemos a que os dirijáis en público a nuestros hijos, mujeres o en general al pueblo [...] Estaríamos completamente locos nosotros y cualquier ciudad que os permitiera hacer lo que estamos diciendo ahora, antes que las autoridades decidan si lo que hacéis es divulgable y conveniente para que se exponga en público. Sí pues, oh vástagos de las dulces musas, haced primero ante las autoridades una demostración de vuestros encantos, y si de la comparación con lo nuestro resulta evidente que son iguales o mejores, os daremos un coro; de lo contrario, amigos, nunca os lo podríamos dar ${ }^{86}$.

Como puede apreciarse aquí, y lo mismo vale para la República, Platón "expulsa a los poetas de su estado ideal, pero no a todos, ciertamente" 87 . De hecho, en contraparte a la "expulsión de los poetas" 88 , dice Platón en República: "Debemos buscar artistas capaces de seguir excelentemente la naturaleza de lo bello y lo conveniente" 89 ; y más adelante: el mal artista "puede imitar con la palabra o con la pintura cualquier arte o cualquier oficio, pero no sabe nada acerca de ellos", mientras que el "buen" artista "ha de poseer siempre conocimiento de lo que crea"90. Cuando dice "conocimiento" se está refiriendo, seguramente, a la posesión del eidos - la Forma, la Idea. En otras palabras: Platón no admite indiferentemente cualquier manifestación artística; lo que equivale a decir que, desde el punto de vista de la excelencia del arte, no todo es legítimo - y, sobre todo, constructivo - para él. Pero esto no significa que todas las manifestaciones artísticas deban ser desterradas por engañosas y perniciosas. De hecho, en el Libro III de República, en el contexto de la reflexión en torno a la educación ideal de los ciudadanos, Sócrates estipula

\footnotetext{
86 PLATÓN. Leyes VII, 817a - 817d.

87 GRUBE. El Pensamiento de Platón, p. 284. Cfr. también pp. 289 et seq.

88 PLATÓN. República III 398a.

89 PLATÓN. República III 401c.

90 PLATÓN. República X 596d-598e.

La vida es sueño, de Calderón de la Barca - ante el tribunal de la Kallipolis y el veredicto de Schopenhauer
} 
que ésta deba basarse en dos pilares: gimnasia para el cuerpo, y música para el alma. En tal contexto, dice Sócrates:

La educación musical es de suma importancia debido a que el ritmo y la armonía son lo que más penetra en el interior del alma y la afecta más vigorosamente, trayendo consigo la gracia, y crea gracia si la persona está debidamente educada, no si no lo está. Además, aquel que ha sido educado musicalmente como se debe es el que percibirá más agudamente las deficiencias y la falta de belleza, tanto en las obras de arte como en las naturales, ante las que su repugnancia estará justificada; alabará las cosas hermosas, regocijándose con ellas y, acogiéndolas en su alma, se nutrirá de ellas hasta convertirse en un hombre de bien. Por el contrario, reprobará las cosas feas - también justificadamente - y las odiará ya desde joven, antes de ser capaz de alcanzar la razón de las cosas; pero, al llegar a la razón, aquel que se haya educado del modo descrito le dará la bienvenida como algo familiar ${ }^{91}$.

Cuáles manifestaciones artísticas son apropiadas para la formación temprana del carácter, cuáles no y bajo qué condiciones, es un asunto que el discípulo de Sócrates desarrolla de manera detallada y sobre el cual no podemos detenernos aquíp ${ }^{92}$. Lo que sí resulta imprescindible destacar para los fines que nos convocan es que existe, en Platón, no solo una valoración positiva del arte, sino un fuerte criterio para rechazar - o admitir las obras con pretensiones artísticas. Ese criterio consiste, grosso modo, en el modo en que dichas obras se relacionen con y propicien un movimiento hacia lo verdadero, lo bueno y lo bello - tríade clave en el pensamiento platónico. Pero más allá de las perpetuas polémicas suscitadas por estas cuestiones, para hacer justicia al antiguo debemos anotar que su valoración positiva de las artes y lo sensible está presente en otros diálogos ${ }^{93} \mathrm{y}$, hasta podría decirse, en todos los diálogos, pues la preocupación por hacer de sus escritos algo bello es patente y, si bien la sustancia de los mismos es filosófica, su forma y narrativa están compuestas en un tono marcadamente literario, constituyéndose así en una “construcción poética de un pensamiento conceptual”94. Platón es él mismo, en pocas palabras, "tan artista como filósofo"95.

Como Platón, Schopenhauer entiende que la mayoría de las exposiciones artísticas no son dignas de aplauso filosófico: cuando el alemán defiende la poesía como espacio

\begin{tabular}{l}
91 PLATÓN. Rep. III 401d-402a \\
92 Cf. Pautas para los ritmos etc. Rep. III \\
93 Cf. Principalmente el Banquete. \\
94 BENOIT, H. Em busca da Odisséia dialógica..., p. 9. \\
95 GRUBE, G. M. A. El Pensamiento de Platón, p. 275. \\
\hline La vida es sueño, de Calderón de la Barca - ante el tribunal de la Kallipolis y el veredicto de Schopenhauer
\end{tabular} 
privilegiado de exposición de las Ideas, se refiere solamente a las obras excepcionales del "genio". Así, para completar nuestro experimento, imaginemos el "tribunal estético" de la ciudad ideal de República y a Schopenhauer como juez del drama calderoniano. Luego de haber reconocido, del modo hasta ahora presentado, la riqueza epistemológica, estética, ética y, en fin, filosófica como un todo, parecen haber buenas chances de que La Vida es Sueño, de Calderón de la Barca, sea bienvenida en la Kallipolis.

\section{Referencias bibliográficas}

ARAMAYO, R. Estudio Preliminar. In: ARAMAYO, R. (Org.). Los Designios del Destino. Madrid: Editorial Tecnos / Grupo Anaya, S. A., 2008.

BENOIT, Héctor, Em busca da Odisséia dialógica, Editora da Universidade Estadual de Campinas, São Paulo, 2004.

BRIONES, A. V. Ensayo sobre la obra de Calderón. Madrid: Ateneo, 1958.

BRIONES, A. V. Introducción - Vida y Obra de Calderón. In: CALDERÓN DE

CLAROS, Luis Fernando M. Schopenhauer en España. In: Daimón, Revista de Filosofía. N. 8. 1994. COSTA RUGNITZ, N. Estrutura e Dinâmica da psyché na República de Platão, Campinas/SP: Editora da UNICAMP. 2012. Disponible aquí.

CALDERÓN DE LA BARCA, P.. La Vida es Sueño. Buenos Aires: Editorial Betina, 2006.

CALDERÓN DE LA BARCA. La Vida es Sueño. Passerino Editore. Kindle ed.; posición 1168

DEUSSEN, P.. Schopenhauer und die Religion. In: P. Deussen (Org.). Viertes Buch der SchopenhauerGesellschaft - 1915. Colônia: Verlag der Schopenhauer-Gesellschaft, 1915.

FAZIO, D., KOSSLER, M., LÜTKEHAUS, L. Arthur Schopenhauer e la sua scuola. Lecce: Pensa MultiMedia, 2006.

GALVÃO, A. R. El príncipe constante: do nobre ao infanto santo. Dissertação de mestrado Universidade Federal Fluminense. 2006.

GERMER, G. M. O Belo e o Bom em Schopenhauer. Campinas/SP: Editora da UNICAMP. 2010. Disponible aquí.

GRUBE, G. M. A.. El pensamiento de Platón. Trd. Tomás Calvo, Gredos, Barcelona, 1973.

GÜNTERT, G. Schopenhauer und Nietzsche in der Ästhetik des spanischen Romans um 1900. In: INGENKAMP, H., BIRNBACHER, D., BAUMANN, L. (Org.). Schopenhauer-Jahrbuch. Bd. 74. Würzburg: Verlag Königshausen und Neumann, 1993. pp. 115-137.

HEIDEGGER, M. Nietzsche. 5a edição. Verlag Grünther Neske Pfulligen, 1961.

LORENZO, Giuseppe de. Divagazioni sul Don Quichote de la Mancha. In: HÜBSCHER, A.. (Org.). Schopenhauer-Jahrbuch. Bd. 32. Berlin: Verlag August Lutzeyer. 1945-48, pp. 116-123.

PLATÓN. Obras Completas. Trad. Conrado Eggers Lan. Biblioteca Básica Gredos, Madrid, 1998.

PLATÓN. Leyes. Akal, Barcelona, 1988.

REICHENBERGER, Kurt \& Roswitha. Bibliographisches Handbuch der Calderón-Forschung / Manual bibliográfico calderoniano (I): Die Calderón-Texte und ihre Überlieferung durch Wichser. Kassel, Edition Reichenberger, 1979.

SCHOPENHAUER, Arthur. Sämtliche Werke in fünf Bänden. Stuttgart/Frankfurt am Main: Suhrkamp, 1986.

SCHOPENHAUER, Arthur. O Mundo como Vontade e como Representação. Tomo I. Trad. Jair Barboza, São Paulo: Editora Unesp, 2005.

SCHOPENHAUER, A. O Mundo como Vontade e como Representação. Tomo II. Trad. Jair Barboza. São Paulo: Editora Unesp, 2015.

SCHOPENHAUER, A. Metafísica do Belo. Trad. Jair Barboza. São Paulo: Editora Unesp, 2003.

SCHOPENHAUER, A. Senilia. In: VOLPI, Franco, ZIEGLER, Ernest (Org.). Trad. Roberto Bernet. 
Barcelona: Herder Editorial, 2010.

STROUD, M. D. Pedro Calderón de La Barca. IN: Spanish Dramatists of the Golden Age: A BioBibliographical Sourcebook. Ed. Mary Parker. Westport: Greenwood, 1998.

ZIEGLER, Ernest. Introducción. In: SCHOPENHAUER, A. Senilia. VOLPI, Fracon, ZIEGLER, Ernest (Org.). Trad. Roberto Bernet. Barcelona: Herder Editorial, 2010.

Recebido: $11 / 01 / 18$

Received: 01/11/18

Aprovado: 22/01/18

Approved: 01/22/18 